\title{
A Látrányi Puszta Természetvédelmi Terület gerinces (Vertebrata) faunájának felmérése
}

\author{
LANSZKI JÓZSEF ${ }^{1}$ és NAGY LÓRÁNT ${ }^{2}$
}

\begin{abstract}
'Kaposvári Egyetem, Állattudományi Kar, Ökológiai Munkacsoport, H-7401 Kaposvár, Pf. 16., Hungary
Somogy Megyei Múzeum, Természettudományi Osztály, H-7400 Kaposvár, Fő út 10., Hungary
\end{abstract}

LANSZKu J., NAGY L.: Investigation on vertebrata fauna of the Látrányi Puszta Nature Conservation Area

Abstract: Diet analysis of carnivores and long-eared owl, live trapping of small mammals and direct observation of other vertebrates was performed on Látrányi Puszta Nature Conservation Area. During the survey 22 mammals, 56 birds, 4 reptiles, 5 amphibians and 11 fish species were observed. The occurrence of the strictly protected otter (Lutra lutra) and bee-cater (Merops apiaster) was frequent. Additionally, there are 62 protected species. We proposed the amplification of the protected area to north and east.

Key words: vertebrates, diet anlysis, carnivores

\section{Bevezetés}

Az 1992-ben védetté nyilvánított Látrányi Puszta Természetvédelmi Terület a DunaDráva Nemzeti Park Igazgatóság kezelésében áll. A külső-somogyi dombok közé ékelödő védett terület kis kiterjedése (223,6 ha) ellenére mozaikosan sokféle élöhelyet foglal magába, de meghatározó a gyep (rét és legelö), melynek aránya mintegy $72 \%$-ot tesz ki. A száraz homoki gyepek, a nedves mocsárrétek, a patak menti kaszálórétek, a kis erdőfoltok sok érdekes és ritka állat és növényfajnak biztosítanak élöhelyet és menedéket. A terület határa mentén folyik a Tetves-patak, mely a Balatoni Halgazdaság Irmapusztai kerületének egyik tápláló vízfolyása. A területen korábban a gerinces faunát részletesen nem kutatták, de a védetté nyilvánítás idején bizonyos faunisztikai adatok gyüjtése megtörtént (ÁBRAHÁM et al. 1994).

A terület gerinces faunájának feltérképezése érdekében, a Környezetvédelmi Minisztérium támogatásával részben közvetett módszereket alkalmaztunk, így ragadozó emlősök hullaték analízisét és bagolyköpet vizsgálatot, részben pedig közvetlen módszereket, így terepi megfigyelẻst és elevenfogó kisemlös csapdázást.

\section{Anyag és módszer}

㤸

\section{Hullaték analizis}

A ragadozó emlősök hullatékának gyüjtése 2001. júniusa és 2002. májusa között, az 1 . ábrán jelölt élőhelyeken $\left(46^{\circ} 44^{\prime}\right.$ É, $\left.17^{\circ} 45^{\prime} \mathrm{K}\right)$, valamint a Tetves patak mentén, hathetenkénti gyakorisággal zajlott. A szárazföldi ragadozók táplálkozás-ökológiai vizsgálata érdekében bejárt útvonal hosszúsága $3,8 \mathrm{~km}$, a vidránál a Tetves-patak mentén és hidak alatt $1,3 \mathrm{~km}$ volt. A gyüjtött mintaszám az alábbiak szerint alakult, vidra: 234 , nyest: 31 és vörösróka: $103 \mathrm{db}$. A faji hovatartozást illetően bizonytalan eredetü mintákból az ürü- 
lékben található, tisztálkodás során lenyelt ragadozó szőrök morfológiai vizsgálatát elvégeztük. A táplálék taxonok meghatározása az emlösöknél koponyacsontok, fogazat és szőrmorfológia (SCHMIDT 1967, MÄrz 1972, DEBROT et al. 1982, UjHELYI 1989, TEERINK 1991, saját referencia gyüjtemény) a madaraknál toll és koponyacsontok (BRowN et al. 1993), a hüllőknél szarupikkelyek és csontok (DELY 1983), a kétéltüeknél csontok (PAUNOVIC 1990), a halaknál pikkely, garatfog és koponyacsontok (BERINKEY 1966, PINTÉr 1989, KEMENES 1993, KNOLLSEISEN 1996), a gerincteleneknél kültakaró (pl. MócZÁR 1969) alapján történt. A tízlábú rákokat (folyami- és kecskerák) Körmendi Sándor, a fenékjáró küllö garatfogakat Sallai Zoltán határozta meg.

A táplálék-összetételt a hullatékokban előforduló táplálék taxonok százalékos előfordulási gyakorisága alapján számítottuk ki, melynek kifejezése a minimális egyedszám alapján történt. A százalékos elöfordulási gyakoriság mellett a fogyasztott táplálék biomassza szerinti összetételét is kiszámoltuk. Ennek érdekében fajonként súlyozó faktorokat alkalmaztunk JEDRZEJEWSKA és JEDRZEJEWSKI (1998) útmutatása alapján.

A mintákban talált emészthetetlen (általában szervetlen) anyagot, valamint a vizsgált ragadozótól származó (1-5 db) szörszálat, amelyeket tisztálkodás során, tehát nem táplálékként nyeltek le, nem vettük figyelembe a számításoknál.

A területen Rozner György által 1999 márciusában gyüjtött 4 db, valamint 2002. februárjában gyüjtött $3 \mathrm{db}$ erdei fülesbagoly köpet feldolgozásakor csak a táplálék fajok esetszámát adtuk meg. A területen 2001 április 24-én ürgelyukak számlálása zajlott, melyet Nagy Lóránt, Pintér András és Rozner György végzett.

\section{Kisemlösök elevenfogó csapdázása}

A kisemlős faunisztikai vizsgálathoz az elevenfogó csapdázás módszerével 2001. júliusban dolgoztunk. Hagyományos üvegajtós facsapdát alkalmaztunk, melynek mérete $18 \times 7 \times 7 \mathrm{~cm}$ volt. Csaléteknek diót, kukoricát és szalonnát használtunk. A csapdákat 4 éjszakára helyeztük ki. Az ellenőrzés korareggel és este történt, melyet már a kihelyezés estéjén is elvégeztünk. A befogott kisemlősök egyedi jelölése a rágcsálóknál elterjedten alkalmazott ujjperc levágással történt (CSORBA és PECSENYE 1997). Három mintaterületen területenként $50 \mathrm{db}$ csapdát helyeztünk el vonal-transzekt módszer alkalmazásával. A szomszédos csapdák egymástól való távolsága $10 \mathrm{~m}$ volt. Az 1-es mintaterületen 7 csapdát égerliget és száraz homoki gyep határán, 11 csapdát mocsárréten és 32 csapdát száraz homoki gyepen helyeztünk el. A 2-es és 5-ös kapcsolt mintaterületen 13 csapdát kavicsgödörben, bokorfüzes és nyílt homoki gyep határán, további 37 csapdát erdő és homoki gyep szegélyvonalán helyeztünk el. A 4-es mintaterületen mind az 50 csapdát mocsárrét helyén kialakult kaszálóréten, bokorfüzes és akácligetek közelében helyeztük el.

\section{Eredmények}

Táplálék-összetétel vizsgálat eredményei

A területen élő nyest nyári-öszi összevont táplálékában (1. táblázat) elöfordulási gyakoriság alapján a gerinctelenek és gyümölcsök azonos aránnyal (34\%) szerepeltek, biomassza számítás alapján viszont a háziállatok domináltak (47\%). Közöttük a házinyúl volt a legfontosabb. A gyümölcsök (42\%) másodlagosan fontos szerepet töltöttek be, a kisemlösök és a madarak fogyasztása pedig ebben az időszakban nem volt jelentős.

A téli és a tavaszi összevont időszakban a nyest leggyakrabban kisemlösöket fogyasztott $(40 \%)$ és ezek biomasszája meghatározó volt $(76 \%)$. Legfontosabb táplálékot a mezei pocok $(59 \%)$ jelentett. Háziállat vágási maradék szerepelt viszonylag jelentősebb biomassza számítás szerinti aránnyal $(13 \%)$, a többi táplálék taxon szerepe jelentéktelen volt. 


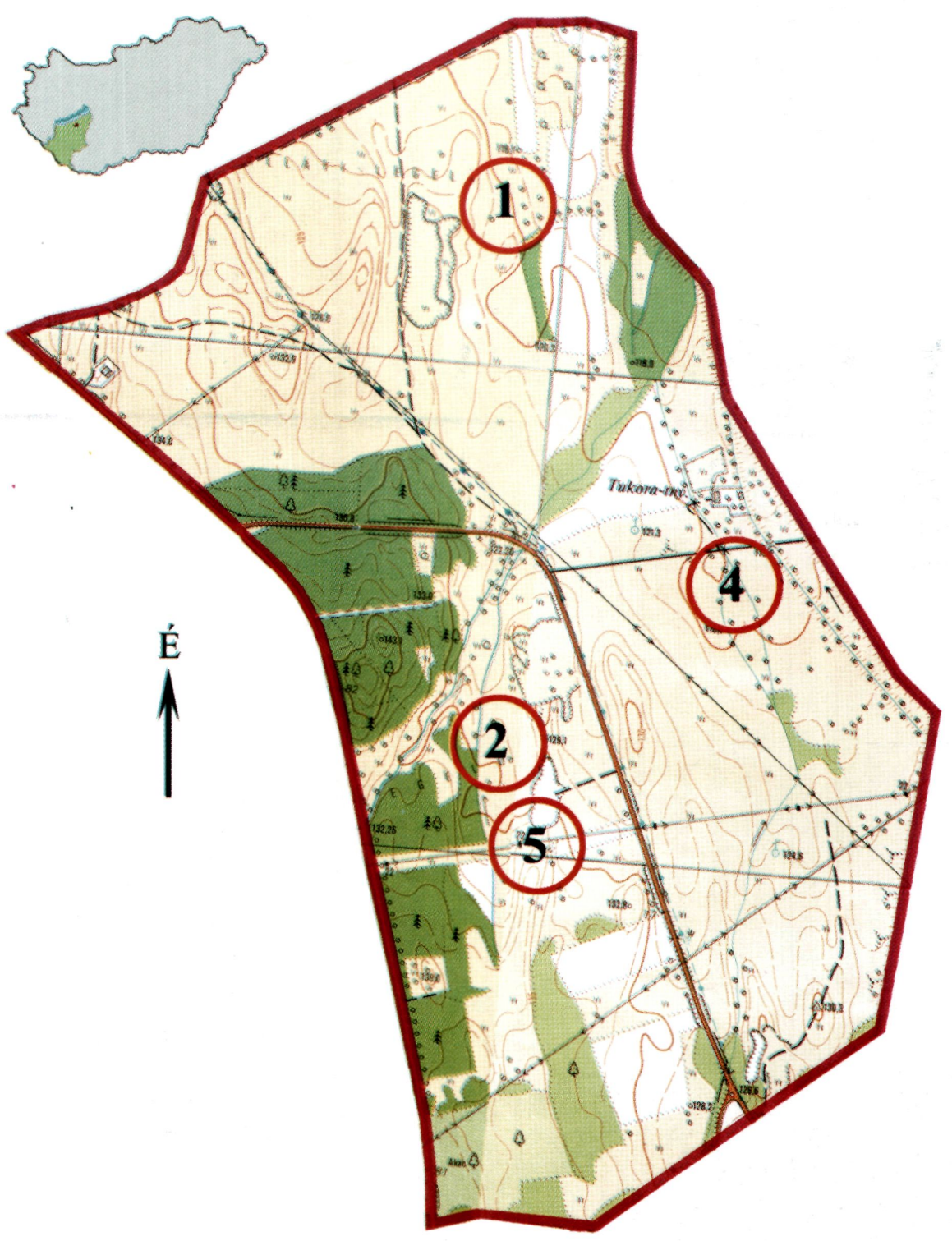




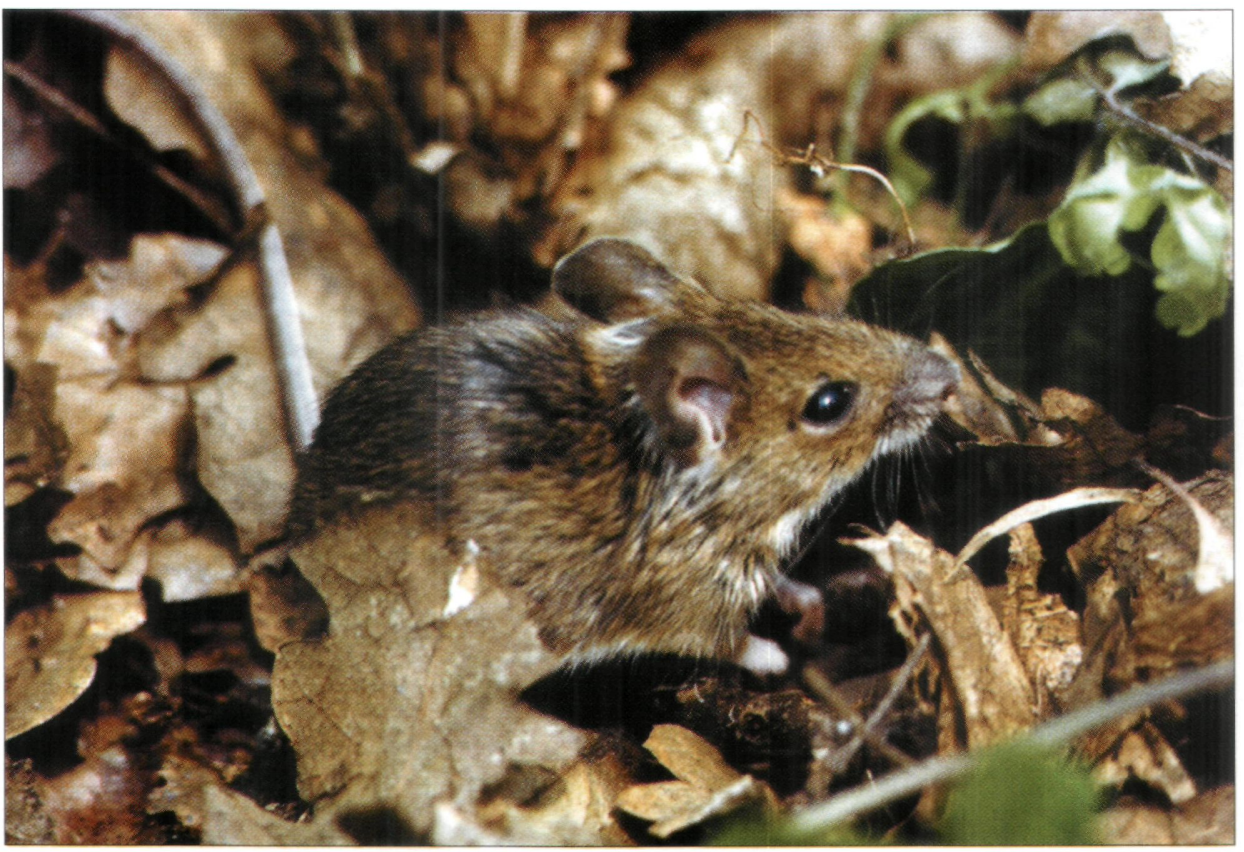

2. ábra: A közönséges erdeiegér (Apodemus sylvaticus) gyakori rágcsálója a fás területeknek

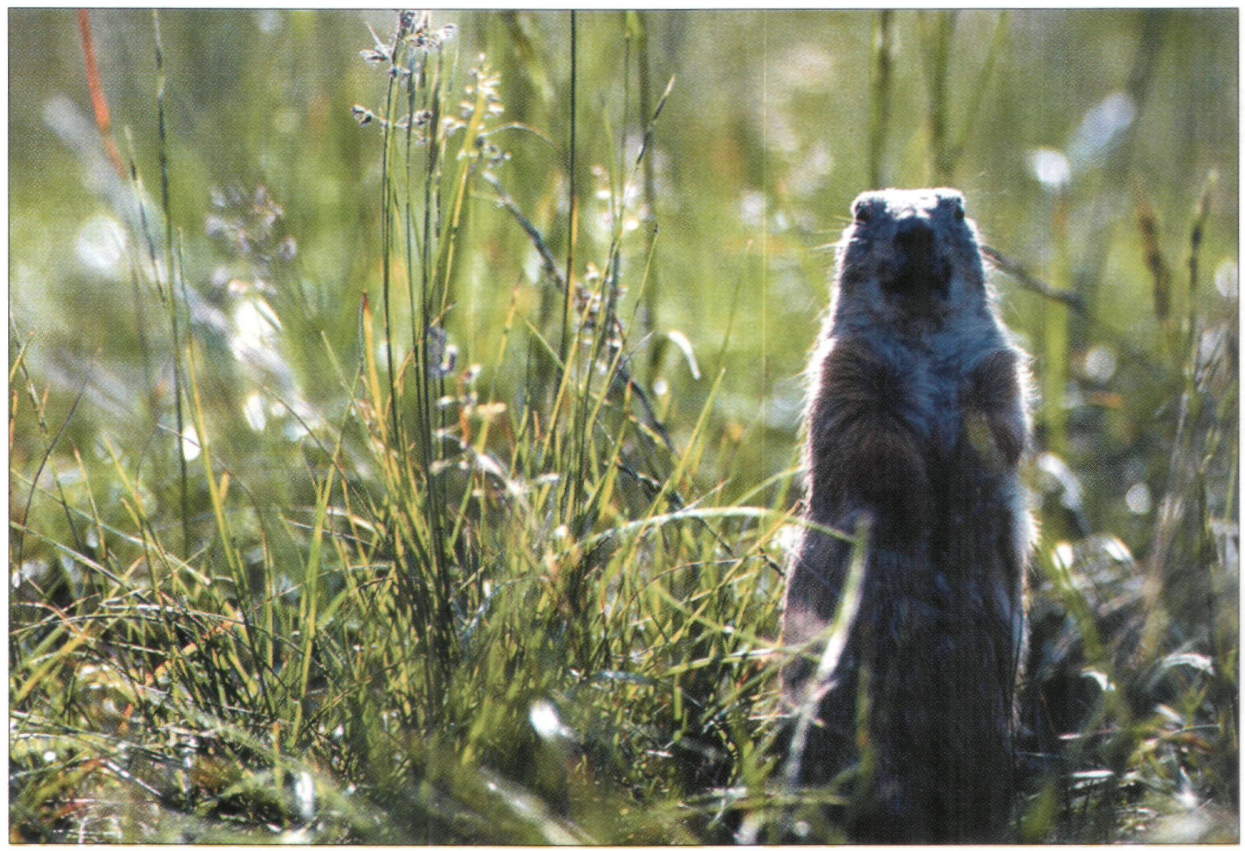

3. ábra: A védett terület ürge (Spermophilus citellus) populációja jelentős természeti értéket képvisel Fotó: Török József 


\section{1. táblázat: A nyest táplálék-összetétele}

\begin{tabular}{|c|c|c|c|c|}
\hline \multirow[t]{2}{*}{ Táplálék taxon } & \multicolumn{2}{|c|}{ Nyártõsz } & \multicolumn{2}{|c|}{ Tél+tavasz } \\
\hline & $\mathrm{E} \%$ & B\% & $\mathrm{E} \%$ & B\% \\
\hline Kisemlõsök összesen & 11,4 & 6,7 & 40.0 & $\mathbf{7 5 . 5}$ \\
\hline Cickány (Soricidae spp.) & 2,9 & 2,2 & & \\
\hline Mezei pocok (Microtus arvalis) & 5,7 & 4,3 & 28.0 & 59.0 \\
\hline Pocokféle (Microtus spp.) & & & 4.0 & 11.6 \\
\hline Közönséges erdeiegér (Apodemus sylvaticus) & 2,9 & 0,2 & 4.0 & 4.7 \\
\hline Erdeiegér (Apodemus spp.) & & & 4.0 & 0.2 \\
\hline Csülkös vadak összesen & & & 4.0 & 3.7 \\
\hline Ōz (Capreolus capreolus) & & & 4.0 & 3.7 \\
\hline Háziállatok összesen & 8,6 & 45,7 & 8.0 & 14.4 \\
\hline Kecske/szarvasmarha & & & 4.0 & 12.6 \\
\hline Házinyúl & 2,9 & 40,5 & & \\
\hline Baromfi & 2,9 & 4,3 & 4.0 & 1.7 \\
\hline Baromfi tojás & 2,9 & 0,9 & & \\
\hline Madarak összesen & 11,4 & 3,7 & 8.0 & 3.6 \\
\hline Énekesmadarak (Passeriformes spp.) & 8,6 & 0,6 & 4.0 & 3.4 \\
\hline Közepes méretû madár (Aves spp.) & 2,9 & 3,2 & & \\
\hline Tojás & & & 4.0 & 0.2 \\
\hline Hüllõk és kétéltûek összesen & & & 4.0 & 0.2 \\
\hline Béka (Anura spp.) & & & 4.0 & 0.2 \\
\hline Gerinctelenek összesen & $\mathbf{3 4 , 3}$ & 2,1 & 8.0 & 1.2 \\
\hline Sáska (Acrioidea spp.) & 2,9 & 0,8 & & \\
\hline Ragyás/rezesfutrinka (Carabus spp.) & 2,9 &.+ & 4.0 & 0.1 \\
\hline Gyászfutó (Pterostichus spp.) & 8,6 & 0,5 & & \\
\hline Fémfutó (Harpalus spp.) & 2,9 &.+ & & \\
\hline Bogár (Coleoptera spp.) & 8,6 & 0,6 & & \\
\hline Bogár (Coleoptera spp.) lárva & & & 4.0 & 1.1 \\
\hline Darázs (Vespidae spp.) & 5,7 & 0,2 & & \\
\hline Rovar (Insecta spp.) & 2,9 &.+ & & \\
\hline Növények összesen & 34,3 & 41,6 & $\mathbf{2 8 . 0}$ & 1.5 \\
\hline Csipkebogyó (Rosa canina) & & & 16.0 & 1.2 \\
\hline Szõlõ (Vitis vinifera) & 5,7 & 7,6 & & \\
\hline Szeder (Rubus spp.) & 11,4 & 8,4 & & \\
\hline Cseresznye (Cerasus avium) & 8,6 & 7,2 & 4.0 & 0.1 \\
\hline Kökény (Prunus spinosa) & 5,7 & 11,8 & 4.0 & 0.1 \\
\hline Szilva (Prunus domestica) & 2,9 & 6,6 & & \\
\hline Mag & & & 4.0 &.+ \\
\hline Mintaszám (n) & 14 & & 17 & \\
\hline Táplálék elemek száma (k) & 35 & & 25 & \\
\hline
\end{tabular}

E\% - előfordulási gyakoriság; B\% - fogyasztott táplálék biomasszája szerinti összetétel; + - 0,05\% alatt.

A vörösróka táplálkozásában egész évben legfontosabb szerepet a kisemlösök töltöttek be, melyek biomassza számítás szerinti aránya 39 és $58 \%$ között mozgott (2. táblázat). Közülük meghatározó volt a mezei pocok fogyasztása, de számos egyéb faj is előfordult a táplálék listán (2. táblázat). Nyári időszakban számottevő volt az ürge fogyasztása (biomassza számítás szerinti aránya 6,4\%). A nagyvad tetemek fogyasztása nyáron és ősszel nem volt jelentős, télen és tavasszal viszont $10 \%$-ot tett ki. A védett terület kis kiterjedésével, a lakott területek közelségével, valamint az illegális hulladéklerakással is összefügg, hogy a háziállat (nyáron baromfi, az év többi részében házinyúl) fogyasztás 


\section{2. táblázat: A vörösróka táplálék-összetétele}

\begin{tabular}{|c|c|c|c|c|c|c|}
\hline \multirow[t]{2}{*}{ Tápplálék taxou } & \multirow{2}{*}{\begin{tabular}{|c|} 
Nyár \\
E\%
\end{tabular}} & \multirow{2}{*}{$\mathrm{B} \%$} & \multirow{2}{*}{$\begin{array}{c}\mathbf{S} s \mathbf{2} \\
\mathrm{E} \%\end{array}$} & \multirow[b]{2}{*}{$\mathrm{B} \%$} & \multicolumn{2}{|c|}{ Tél+tavasz } \\
\hline & & & & & $\mathrm{E} \%$ & $\mathrm{~B} \%$ \\
\hline Kisemlös összesen & 30.3 & 38.9 & 32.4 & 57.9 & 50.0 & 51.7 \\
\hline Erdei pocok (Clethrionomys glareolus) & 2.8 & 6.9 & 2.8 & 8.8 & & \\
\hline Mezei pocok (Microtus arvalis) & 11.9 & 14.8 & 25.4 & 43.9 & 32.8 & 30.5 \\
\hline Vizipocok (Arvicola terrestris) & 2.8 & 2.6 & 1.4 & 1.6 & 1.7 & 3.5 \\
\hline Pocokféle (Microtus spp.) & 2.8 & 3.8 & & & 1.7 & 1.5 \\
\hline Örge (Spermophilus citellus) & 3.7 & 6.4 & & & 1.7 & 0.1 \\
\hline Közönséges erdeiegér (Apodem us sylvaticus) & 1.8 & 2.6 & & & 1.7 & 4.6 \\
\hline Sárganyakú erdeiegér (Apodem us flavicollis) & & & & & 1.7 & 1.0 \\
\hline Pirókegér (Apodemus agrarius) & 0.9 & 0.9 & & & 5.2 & 0.9 \\
\hline Erdeiegér (Apodem us spp.) & 0.9 & + & & & & \\
\hline Törpeegér (Micromys minutus) & & & 2.8 & 3.6 & & \\
\hline Vándorpatkány (Rattus norvegicus) & 0.9 & 0.2 & & & & \\
\hline Mókus (Sciunus vulgaris) & 0.9 & 0.5 & & & 1.7 & 1.2 \\
\hline Rágcsáló (Rodentia spp.) & 0.9 &.+ & & & & \\
\hline Mezein yúl (Lepus europaeus) & & & & & 1.7 & 8.4 \\
\hline Csülkôs vadak összesen & 2.8 & 0.5 & 5.6 & 0.7 & 6.9 & 10.5 \\
\hline Vaddisznó (Sus scrofa) & 1.8 & 0.1 & & & 1.7 & 8.9 \\
\hline Gímszarvas (Cervus elaphus) & & & & & 1.7 & 0.1 \\
\hline $\mathrm{O} \mathrm{z}$ (Capreolus capreolus) & 0.9 & 0.3 & 5.6 & 0.7 & 3.4 & 1.5 \\
\hline Házílllatok összesen & 7.3 & 29.5 & 2.8 & 15.4 & 5.2 & 21.2 \\
\hline Házinyúl & & & 1.4 & 13.7 & 3.4 & 19.3 \\
\hline Kecske/szarvasmarha & 0.9 & 0.2 & & & & \\
\hline Baromfi & 6.4 & 29.3 & 1.4 & 1.6 & 1.7 & 1.9 \\
\hline Madarak összesen & 7.3 & 3.8 & 2.8 & 0.3 & 6.9 & 2.2 \\
\hline Énekesmadarak (Passeriformes spp.) & 5.5 & 3.7 & 1.4 & 0.1 & 3.4 & 0.7 \\
\hline Közepes méretû madár (Aves spp.) & 0.9 & + & 1.4 & 0.1 & 3.4 & 1.5 \\
\hline Tojás & 0.9 & + & & & & \\
\hline Hüllôk és kétéltâek összesen & 1.8 & 0.7 & & & & \\
\hline Gyik (Sauria spp.) & 0.9 &.+ & & & & \\
\hline Béka (Anura spp.) & 0.9 & 0.7 & & & & \\
\hline Halak összesen & & & & & 1.7 & 1.2 \\
\hline Ponty (Cyprinus carpio) & & & & & 1.7 & 1.2 \\
\hline Gerinctelenek összesen & 26.6 & 2.6 & 19.7 & 0.2 & 3.4 & 0.2 \\
\hline Sáska (Acrioidea spp.) & 5.5 & 0.9 & 2.8 & ++ & & \\
\hline Imádkozó sáska (Mantis religiosa) & 0.9 & ++ & 2.8 &.+ & & \\
\hline Lótücsök (Gryllotalpa gryllotalpa) & & & & & 1.7 & + \\
\hline Aranyettyes futrinka (Carabus hortensis) & 1.8 & + & & & & \\
\hline Ragyás/rezesfutrinka (Carabus spp.) & 2.8 & + & 1.4 & + & & \\
\hline Kékfutrinka (Carabus violaceus) & 2.8 & ++ & 1.4 & + & & \\
\hline Bōrfut rinka (Carabus coriaceus) & 0.9 &.+ & 5.6 &.+ & & \\
\hline Gyászfutó (Pterostichus spp.) & 0.9 & + & 1.4 & 0.2 & & \\
\hline Futóbogár (Carabidae spp.) & & & 1.4 & ++ & & \\
\hline Szarvasbogár (Lucanus cervus) & 1.8 &.+ & & & & \\
\hline Májusi cserebogár (Melolontha melolontha) & 1.8 & 0.4 & & & & \\
\hline Bogár (Coleoptera spp.) & 3.7 &.+ & 1.4 &.+ & & \\
\hline Bogár (Coleoptera spp.) lárva & & & & & 1.7 & 0.2 \\
\hline Fémzöld döglégy (Lucilia caesar) & 1.8 & + & & & & \\
\hline Rovar (Insecta spp.) & & & 1.4 & + & & \\
\hline Tízlábú rák (Astacus spp.) & 1.8 & 1.1 & & & & \\
\hline Növények összesen & 23.9 & 24.0 & 36.6 & 25.5 & 25.9 & 12.0 \\
\hline Szộlō (Vitis vinifera) & 0.9 & 1.8 & 14.1 & 11.9 & 3.4 & 3.1 \\
\hline Szeder (Rubus spp.) & 7.3 & 8.4 & & & & \\
\hline Cseresznye (Cerasus avium) & 2.8 & 2.3 & & & & \\
\hline Szilva (Prunus domestica) & 6.4 & 11.2 & 5.6 & 4.8 & 3.4 & 2.2 \\
\hline Kökény (Prunus spinosa) & & & 8.5 & 8.3 & 8.6 & 6.4 \\
\hline Körte (Pyrus spp.) & & & 1.4 & 0.1 & & \\
\hline Dió (Juglans regia) & & & 1.4 & + & & \\
\hline Csipkebogyó (Rosa canina) & & & 1.4 & 0.2 & 1.7 & 0.2 \\
\hline Gyümölcs, meghatározhatatlan & & & 1.4 & ++ & & \\
\hline Mag & 1.8 &.+ & & & 5.2 & 0.1 \\
\hline Pázsitfûfélek (Gramineae spp.) & 4.6 & 0.2 & 2.8 & 0.1 & 3.4 & + \\
\hline Mintaszám (n) & 40 & & 26 & & 37 & \\
\hline Táplálék taxonok száma (k) & 109 & & 71 & & 58 & \\
\hline
\end{tabular}

E\% - előfordulási gyakoriság; B\% - fogyasztott táplálék biomasszája szerinti összetétel; + - 0,05\% alatt. 
jelentős volt (15-30\%). Madarak, valamint gerinctelenek gyakran szerepeltek a róka táplálékában, de fogyasztott biomasszájuk alacsony volt. A növények között nyáron a szilva, ősszel a szőlö, télen a kökény és a hullott gyümölcsök voltak a legfontosabbak.

A Tetves patak mentén élő vidra táplálékában kétéltüek és hüllők töltöttek be elsődlegesen fontos szerepet ősztöl tavaszig $(60,68$, ill. 44\%, évszakonként), csak nyáron voltak $(21 \%)$ másodlagosan fontosak (3. táblázat). A táplálékmaradványok között mocsári teknős (Emys orbicularis) páncélját fedő héj darabjai és siklófélék (Colubridae) is elöfordultak, azonban meghatározó szerepük a kétéltüeknek volt. A kisemlősökből álló táplálékában a vízipocok fogyasztása volt számottevő őszi és téli időszakban (7, ill. $3 \%)$. Madarak alacsony arányban (1\% alatt) fordultak elő táplálékként. A halak részaránya egész évben alacsony szinten mozgott (17-27\%), legkevesebb volt fogyasztásuk nyáron, és legtöbb tavasszal. A halfajok között lassú folyású patakokra és halastavakra jellemző fajok egyaránt előfordultak. A terület különleges adottságát mutatja, hogy nyári időszakban a vidra domináns tápláléka gerinctelenekböl állt. Közülük a tízlábú rákok fogyasztása volt meghatározó (62\%), és a rákok még az őszi-téli időszakban (8-9\%) is jelentős mennyiségben szerepeltek a vidra étlapján.

$\mathrm{Az}$ erdei fülesbagoly táplálékában mezei pocok ( 9 eset) és sárganyakú erdeiegér (Apodemus flavicollis) (1 eset) szerepelt.

\section{Kisemlösök elevenfogó csapdázásának eredménye}

Az egyes alminta területeken kapott, valamint az összesített eredményeket a 4. táblázat szemlélteti. A három élőhely környezeti adottságai eltértek egymástól, de az ott élő kisemlös életközösség szerkezete statisztikailag nem különbözött (Kruskal-Wallis teszt, $\left.\chi^{2}=0,201, \mathrm{df}=2, \mathrm{P}=0,904\right)$. Az 1-es alminta területen legnagyobb gyakorisággal a védett csalitjáró pocok fordult elő. Az elökerült példányok a nedvesebb réthez közeli száraz homokgyepi régióban éltek. Az erdő peremterületén fordultak elő az erdeiegér fajok, valamint az erdei pocok. A náddal szálanként borított mocsárréten egyetlen törpeegeret sikerült fogni, de jellegzetes fészkét nem találtuk meg. A nagy kiterjedésü, száraz homokgyepen a kisrágcsáló sürüség rendkívül alacsonynak bizonyult. A 2-es és 5-ös kapcsolt mintaterületen leggyakoribb faj a pirókegér volt, emellett az erdei egerek fordultak még elő számottevő létszámban. A 4-es alminta területen, az előző területhez hasonló volt a fajösszetétel. Legnagyobb fajgazdagságot a vegyes élöhelyeket magába foglaló 1es területen tapasztaltunk (4. táblázat). A 100 csapdaéjszakára jutó új fogások száma 28,5 , az összes fogásszám 47,9 volt.

A területen végzett ürgelyuk számláláskor 63 lakottnak bizonyult.

\section{Következtetések}

A területbejárások során megfigyelt gerincesek adatait az 5. táblázatban foglaltuk öszsze. A vizsgált időszakban a területen 22 emlös, 56 madár, 4 hüllö, 5 kétéltü és 11 halfajt figyeltünk meg. A Balaton déli partján, így a Látrányi Puszta TT-hez közel fekvő Irmapusztai halastavak madárfaunája a vizsgálatunktól lényegesen gazdagabb (az irodalmat összefoglalta PURGER és FENYöSI 2001), a többi gerinces osztályra vonatkozó irodalom azonban nemcsak a természetvédelmi terület, hanem környékének vonatkozásában is hiányos volt.

A TT északi határa felett elterülő galagonyabokros legelő kiváló élőhely és fészkelő terület több madárfaj számára (pl. poszáták, tövisszúró gébics, fürj, sordély). Az elha- 


\section{3. táblázat: A vidra táplálék-összetétele}

\begin{tabular}{|c|c|c|c|c|c|c|c|c|}
\hline Táplálék taxon & Nyár & & Osz & & Tél & & Tavasz & \\
\hline & $\mathrm{E} \%$ & $\mathrm{~B} \%$ & $\mathrm{E} \%$ & $\mathbf{B} \%$ & $\mathrm{E} \%$ & $\mathrm{~B} \%$ & $\mathrm{E} \%$ & $\mathrm{~B} \%$ \\
\hline Kisemlốsök & 1,3 & + & 12,3 & 6,9 & 3,4 & 3,9 & 1,1 & + \\
\hline Cickány (Soricidae spp.) & & & & & 0,8 & 0,6 & & \\
\hline Pocok (Microtus spp.) & 1,3 & + & & & & & 1,1 & + \\
\hline Vizipocok (Arvicola terrestris) & & & 12,3 & 6,9 & 2,5 & 3,2 & & \\
\hline Madarak & 0,6 & $\mathbf{0 , 1}$ & - & - & 1,7 & 0,9 & - & $=$ \\
\hline Fácán (Phaseanus colchicus) & & & & & 0,8 & 0,8 & & \\
\hline Kistestủ énekesmadár (Passeriformes spp.) & 0,6 & 0,1 & & & 0,8 & 0,1 & & \\
\hline Hüllok és kétéltủek & 19,5 & 21,4 & 37,0 & 60,4 & 47,9 & 68,5 & 36,7 & 44,3 \\
\hline Mocsári teknős (Emys orbicularis) & 1,9 & 2,1 & & & & & & \\
\hline Vizisikló (Natrix natrix) & 0,6 & 0,5 & & & & & & \\
\hline Siklófélék (Colubridae spp.) & 0,6 & 3,6 & & & & & & \\
\hline Hüllö (Reptilia spp.) & 0,6 & 0,3 & & & & & & \\
\hline Zöld levelibéka (Hyla arborea) & & & & & 0,8 & 0,3 & & \\
\hline Barna varangy (Bufo bufo) & 3,3 & 4,8 & 4,1 & 21,3 & 0,8 & $\mathbf{2 , 0}$ & 1,1 & 1,0 \\
\hline Varangy (Bufo spp.) & & & & & 0,8 & 2,3 & & \\
\hline Kecskebéka (Rana esculenta) & 1,3 & 3,8 & 1,4 & 4,0 & 20,2 & 39,8 & 2,2 & 4,1 \\
\hline Tavi-/kecskebéka (Rana spp.) & 1,3 & 0,4 & & & 9,2 & 15,7 & 2,2 & 4,5 \\
\hline Béka (Anura spp.) & 9,8 & 5,9 & 31,5 & 35,1 & 16,0 & 8,4 & 31,1 & 34,8 \\
\hline Halak & 20,1 & 16,7 & 20,6 & $\mathbf{2 2 , 8}$ & $\mathbf{2 1 , 8}$ & 18,9 & 27,8 & 26,8 \\
\hline Ponty (Cyprinus carpio) & & & 1,4 & 3,9 & & & 4,4 & 6,9 \\
\hline Fehér busa (Hypophthalamychthys molitrix) & & & & & & & 1,1 & 1,0 \\
\hline Ezüstkárász (Carassius auratus gibelio) & 1,3 & 1,6 & & & 1,7 & 1,8 & 8,9 & 9,7 \\
\hline Kárász (Carassius spp.) & & & & & 0,8 & 1,3 & & \\
\hline Lapos/dévérkeszeg (Abramis ballerus/A. & & & 2,7 & 3,1 & & & & \\
\hline Bodorka (Rutilus rutilus) & & & 1,4 & 0,6 & 0,8 & 0,7 & & \\
\hline Fenékjáró küllo (Gobio gobio) & 12,4 & 12,2 & 9,5 & 9,9 & 1,7 & 0,9 & 2,2 & 2,1 \\
\hline Kínai razbóra (Pseudorasbora parva) & 0,6 & 0,7 & 1,4 & 1,1 & 7,6 & 3,6 & & \\
\hline Szélhajtó küsz (Alburnus alburnus) & 1,3 & 0,2 & & & 4,2 & 2,7 & 3,3 & 3,0 \\
\hline Pontyféle (Cyprinidae spp.) & 1,3 & 0,2 & & & 0,8 & 0,4 & 3,3 & 3,4 \\
\hline Réti-/vágó csik (Misgurnus fossilis/Cobitis & 0,6 & + & & & & & & \\
\hline Naphal (Lepomis gibbosus) & 0,6 & 0,3 & & & 1,7 & 0,8 & & \\
\hline Csuka (Esox lucius) & & & 1,4 & 0,1 & & & & \\
\hline Sügér (Perca fluviatilis) & & & & & & & 1,1 & + \\
\hline Törpeharcsa (Ictalurus nebulosus) & 0,6 & 0,4 & & & & & & \\
\hline Hal, azonosithatatlan & 1,3 & 1,0 & 2,8 & 4,1 & 2,5 & 6,8 & 3,3 & 0,6 \\
\hline Gerinctelenek & 54,5 & 61,7 & 30,1 & 9,9 & $\mathbf{2 5 , 2}$ & 7,8 & $\mathbf{3 4 , 4}$ & $\mathbf{2 8 , 9}$ \\
\hline Gyászfutó bogár (Pterostichus spp.) & 0,6 & + & 1,4 & + & & & & \\
\hline Fémfutó bogár (Harpalus spp.) & 1,3 & + & & & & & & \\
\hline Sárgaszegélyü csíkbogár (Dytiscus marginalis) & 1,3 & + & 1,4 & + & 1,7 & + & 1,1 & + \\
\hline Csikbogár/csíbor (Dytiscidae/Hydrophilidae) & 1,2 & + & 1,4 & + & & & & \\
\hline Csikbogár/csibor (Dytiscidae/Hydrophilidae) & & & 1,4 & + & & & & \\
\hline Bogár (Coleoptera spp.) & 1,3 & + & 4,1 & + & & & & \\
\hline Darázs (Vespidae spp.) & & & 1,4 & + & & & & \\
\hline Rovar (Insecta spp.) & & & 4,0 & 0,4 & & & & \\
\hline Tízlábú rák (Decapoda spp.) & 47,5 & 61,6 & 13,6 & 8,6 & 22,7 & 7,8 & 33,3 & 28,9 \\
\hline Csiga (Gastropoda spp.) & 1,3 & 0,1 & 1,4 & 0,9 & 0,8 & + & & \\
\hline Növények & 3,9 & + & - & - & - & - & - & - \\
\hline Pázsitfüfélék (Gramineae spp.) & 3,9 & + & & & & & & \\
\hline Mintaszám & 34 & & 81 & & 58 & & 61 & \\
\hline Táplálék elemek száma & 73 & & 154 & & 119 & & 90 & \\
\hline
\end{tabular}




\section{4. táblázat: A kisemlős elevenfogó csapdázások eredménye}

\begin{tabular}{|c|c|c|c|c|c|c|c|c|}
\hline & \multirow{2}{*}{\multicolumn{2}{|c|}{\begin{tabular}{|l|} 
Mintaterület \\
száraz/nedves rét (1) \\
\end{tabular}}} & & & & & & \\
\hline \multirow{2}{*}{ Kisemlös faj } & & & \multicolumn{2}{|c|}{ Erdo/ret $(2,5)$} & \multirow{2}{*}{$\frac{\text { Ret (4) }}{N}$} & \multirow[b]{2}{*}{$\%$} & \multirow{2}{*}{$\frac{\text { Ósszesen }}{\mid \mathbf{N}}$} & \multirow[b]{2}{*}{$\%$} \\
\hline & $\mathbf{N}$ & $\%$ & $\mathbf{N}$ & $\%$ & & & & \\
\hline Pirók erdeiegér (Apodem us agrarius) & 10 & 19,6 & 43 & 60,6 & 29 & 52,7 & 82 & 46,3 \\
\hline Közönséges erdeieger (Apodem us sylvaticus) & 12 & 23,5 & 17 & 23,9 & 14 & 25,5 & 43 & 24,3 \\
\hline Sárganyakú erdeieger (Apodemus flavicollis) & 1 & $\mathbf{2 , 0}$ & 4 & 5,6 & 3 & 5,5 & 8 & 4,5 \\
\hline Törpeeger (Micromys minutus) & 1 & 2,0 & 0 & 0,0 & 0 & 0,0 & 1 & 0,6 \\
\hline Mezei pocok (Microtus arvalis) & 10 & 19,6 & 4 & 5,6 & 6 & 10,9 & 20 & 11,3 \\
\hline Csalitjáró pocok (Microtus agrestis) & 15 & 29,4 & 0 & 0,0 & 1 & 1,8 & 16 & 9,0 \\
\hline Erdei pocok (Clethrionomys glareolus) & 1 & $\mathbf{2 , 0}$ & 3 & 4,2 & 1 & 1,8 & 5 & 2,8 \\
\hline Mezei cickány (Crocidura leucodon) & 1 & 2,0 & 0 & 0,0 & 1 & 1,8 & 2 & 1,1 \\
\hline Ōsszesen: & 51 & & 71 & & 55 & & 177 & \\
\hline Simpson-index & & 4,544 & & 2,313 & & 2,788 & & 3,364 \\
\hline
\end{tabular}

gyott szarkafészkek alkalmasak az erdei fülesbagoly költésére. Több lakott ürgelyuk található ezen a már védett területen kívüli területrészen. A védett terület határainak kiterjesztése erre az élöhelyre indokolt.

A TT határán folyó Tetves patakban élő fokozottan védett vidra (Lutra lutra) táplálékanalízise és a vízparton talált táplálékmaradványok alapján olyan fajok jelenléte bizonyítható, melyek megőrzése természetvédelmi szempontból indokolt. Így kimutatható volt kettő tízlábú rákfaj: a védett folyami rák (Astacus astacus) és a kecskerák (Astacus leptodactylus), valamint a halak közül a védett fenékjáró küllő (Gobio gobio) továbbá csíkfélék (Cobitidae), a hüllök közül pedig a mocsári teknős (Emys orbicularis) jelenléte. A vidrának egy rendszeresen lakott fészekhelye ismert. A patak a jelenlegi állapotában egy kopár medrü csatornához hasonlít. Az értékes állatfajok igényeinek megfelelőbb, természetesebb környezet kialakítása érdekében célszerü lenne a patakmeder rehabilitációs munkáját elvégezni. Ennek során a partközelbe cserjék, takarást nyújtó, de a vízpárologtatást nem fokozó, hanem ellenkezőleg, árnyékot adó növényzet telepítése szükséges. A telepítésnél mindenképp figyelembe kell venni az esetleges árvízvédelmi szempontokat. Jelenleg a vízpartig folyik szántóföldi művelés. A patak mentén fekvő földek tulajdonosaival a müvelés jellegét (vegyszerezés, mütrágyázás, esetleges védőzóna kijelölést) célszerủ lenne egyeztetni. A vízminőségi vizsgálatokat is célszerü elvégeztetni, a tízlábú rákok jelenléte mindenképp kedvező e tekintetben. Nyári időszakban viszont a patak vízállása kritikusan alacsony. Ehhez részben hozzájárul az, hogy a patak medrét (a középső fél méteres sávot) szinte teljes hosszában nád borítja (mely jelentős vízpárologtató is), szük teret adva a vidra és más vízhez kötődő fajok mozgásához és rejtőzködéséhez. A vidra számára nagyon kevés biztonságos kiszálló hely található a bejárt szakaszon ( 2 kövezéses szakasz és 2 híd környéke). Fatörzsek, nagy kövek helyezhetök partközelbe, melyek más fajok (pl. madarak) számára is pihenő, vagy zsákmányszerzésre alkalmas helyet jelenthetnek. A patak közelében húzódó fasor több madárfaj (örvös galamb, vadgerle, zöld küllő, fekete harkály, stb.) fészkelő helye, fenntartása (a többi kis erdőfolttal együtt) fontos.

A területbejárások során sajnos általános szemléletbeli problémákat tapasztaltunk, így égetés, szemétlerakás, falopás, gyep szétvágása gépkocsival, motorral, táblák megrongálása, homok kitermelés is előfordult. A terület kincseinek megőrzés csak akkor lehetséges, ha a környékbeli lakosság elfogadja azt.

Javasoljuk a rókaállomány alapos gyérítését (4 lakott kotorék ismert a területen), ugyanis a róka - a táplálékvizsgálat alapján - jelentős ürgefogyasztó. A szarvasmarha állomány legeltetése (vagy kaszáltatás) a védett terület északi részén, az ürge élőhelyeken kedvezö lenne. 


\section{5. táblázat. A gerinces fauna listája a Látrányi Puszta Természetvédelmi Területen}

\section{Emlősök - Mammalia}

Mezei cickány (Crocidura leucodon) - cs - V

Vakond (Talpa europaea) - m, f - V

Mezei nyúl (Lepus europaeus) - $\mathrm{m}$

Nagy pele (Myoxus glis) - $\mathrm{m}-\mathrm{V}$

Közönséges mókus (Sciurus vulgaris) - h - V

Közönséges ürge (Spermophilus citellus) - m, h - V

Vöröshátú erdeipocok (Clethrionomys glare-

olus) - cs, h

Közönsćges kószapocok (Arvicola terrestris) - $\mathrm{h}$

Csalitjáró pocok (Microtus agrarius) - cs, h - V

Mezei pocok (Microtus arvalis) -cs, $\mathrm{h}$

Törpeegér (Micromys minutus) - cs, $\mathrm{h}-\mathrm{V}$

Pirók erdeiegér (Apodemus agrarius) - cs,h

Sárganyakú erdeiegér (Apodemus flavicollis) - cs, $\mathbf{h}$

Közönséges erdeiegér (Apodemus sylvaticus) - cs, h

Vándorpatkány (Rattus norvegicus) - $\mathrm{h}$

Vörösróka (Vulpes vulpes) - ny, k, h

Nycst (Martes foina) - ny, h

Eurázsiai borz (Meles meles) - h, ny, $\mathrm{k}$

Vidra (Lutra lutra) - h, ny, k - FV

Vaddisznó (Sus scrofa) - ny

Gímszarvas (Cervus elaphus) - a

Európai öz (Capreolus capreolus) - m, ny

Madarak - Aves

Fácán (Phasianus colchicus) - m

Fürj (Coturnix coturnix) - $\mathrm{m}, \mathrm{f}-\mathrm{V}$

Tőkésréce (Anas platyrhynchos) - $\mathrm{m}$

Örvös galamb (Columba palumbus) - $\mathrm{m}, \mathrm{f}-\mathrm{V}$

Vadgerle (Streptopelia turtur) - $\mathbf{m}, \mathbf{f}-\mathrm{V}$

Balkáni gerle (Streptopelia decaocto) - $\mathrm{m}$

Kakukk (Cuculus canorus) - m, "f" - V

Jégmadár (Alcedo atthis) - $\mathrm{m}-\mathrm{V}$

Gyurgyalag (Merops apiaster) - m, f - FV

Nyaktekercs (Jynx torquilla) $-\mathrm{m}-\mathrm{V}$

Zöld küllö (Picus viridis) - $\mathrm{m}, \mathrm{f}-\mathrm{V}$

Fckete harkály (Dryocopus martius) - $\mathrm{m}, \mathrm{f}-\mathrm{V}$

Nagy fakopáncs (Dendrocopos major) - $\mathrm{m}, \mathrm{f}-\mathrm{V}$

Mezci pacsirta (Alauda arvensis) - $\mathrm{m}, \mathrm{f}-\mathrm{V}$

Füsti fecske (Hirundo rustica) - $\mathrm{m}-\mathrm{V}$

Molnárfecske (Delichon urbica) - $\mathrm{m}-\mathrm{V}$

Sárga billegetö (Motacilla flava) - $\mathrm{m}, \mathrm{f}-\mathrm{V}$

Ökörszem (Troglodytes troglodytes) - $\mathrm{m}, \mathrm{f}-\mathrm{V}$

Vörösbegy (Erithacus rubecula) - $\mathrm{m}, \mathrm{f}-\mathrm{V}$

Fülemüle (Luscinia megarhynchos) - $\mathrm{m}, \mathrm{f}-\mathrm{V}$

Rozsdás csuk (Saxicola rubetra) - $\mathrm{m}, \mathbf{f}-\mathrm{V}$

Cigány csuk (Saxicola torquata) - $\mathrm{m}, \mathrm{f} \cdot \mathrm{V}$

Feketerigó (Turdus merula) - $\mathrm{m}, \mathrm{f}-\mathrm{V}$

Fenyôrigó (Turclus pilaris) - $\mathrm{m}-\mathrm{V}$

Énekes rigó (Turdus philomelos) - $\mathrm{m}, \mathrm{f}-\mathrm{V}$

Léprigó (Turdus viscivorus) - $\mathrm{m}-\mathrm{V}$

Berki tücsökmadár (Locustella fluviatilis) - $\mathrm{m}, \mathrm{f}-\mathrm{V}$

Nádi tücsökmadár (Locustella luscinioides) - m, f - V

Fülcmüle sitke (Acrocephalus melanopogon) - $\mathrm{m}, \mathrm{f}-\mathrm{V}$
Foltos nádiposzáta (Acrocephalus schoenobaenus) - $\mathrm{m}, \mathrm{f}-\mathrm{V}$

Énckes nádiposzáta (Acrocephalus palustris) $-\mathrm{m}, \mathrm{f}-\mathrm{V}$

Nádirigó (Acrocephalus arundinaceus) - $\mathrm{m}, \mathrm{f}-\mathrm{V}$

Mezei poszáta (Sylvia communis) - m, f - V

Barátposzáta (Sylvia atricapilla) - $\mathrm{m}, \mathrm{f}-\mathrm{V}$

Csilp-csalp fuzike (Phylloscopus collybita) - $\mathrm{m}, \mathrm{f}-\mathrm{V}$

Kék cinege (Parus caeruleus) - $\mathrm{m}$ - V

Széncinege (Parus major) - $\mathrm{m}, \mathrm{f}-\mathrm{V}$

Sárgarigó (Oriolus oriolus) - $\mathrm{m}-\mathrm{V}$

Tövisszúró gébics (Lanius collurio) - $\mathrm{m}, \mathrm{f}-\mathrm{V}$

Nagy örgébics (Lanius excubitor) - $\mathrm{m}-\mathrm{V}$

Szajkó (Garrulus glandarius) - $\mathrm{m}, \mathrm{f}$

Szarka (Pica pica) - m, f

Dolmányos varjú (Corvus cornix) - $\mathrm{m}$

Vetési varjú (Corvus frugilegus) - $\mathrm{m}-\mathrm{V}$

Seregély (Sturnus vulgaris) - $\mathrm{m}, \mathrm{f}$

Búbos banka (Upupa epops) - $\mathrm{m}$ - V

Mezei veréb (Passer montanus) - $\mathrm{m}-\mathrm{V}$

Zöldike (Carduelis chloris) - $\mathrm{m}(\mathrm{f})-\mathrm{V}$

Tengelic (Carduelis carduelis) - $\mathrm{m}(\mathrm{f})-\mathrm{V}$

Meggyvágó (Coccothraustes coccothraustes) -

m (f) - V

Citromsármány (Emberiza citrinella) - $\mathrm{m}, \mathrm{f}-\mathrm{V}$

Sordély (Miliaria calandra) - $\mathrm{m}, \mathrm{f}-\mathrm{V}$

Barna rétihéja (Circus aeruginosus) - $\mathrm{m}-\mathrm{V}$

Egerészölyv (Buteo buteo) - m, f - V

Vörösvércse (Falco tinnunculus) - $\mathrm{m}$ - V

Erdei fülesbagoly (Asio otus) - h

Hüllök - Reptilia

Mocsári teknős (Emys orbicularis) - h - V

Fürge gyík (Lacerta agilis) - m - V

Zöld gyík (Lacerta viridis) - $\mathrm{m}-\mathrm{V}$

Vízisikló (Natrix natrix) - h, m - V

Kétéltüek - Amphibia

Vöröshasú unka (Bombina bombina) - $\mathrm{m}-\mathrm{V}$

Barna varangy (Bufo bufo) $-\mathrm{h}, \mathrm{m}-\mathrm{V}$

Zöld levelibéka (Hyla arborea) - $\mathrm{m}$ - V

Erdei béka (Rana dalmatina) - $\mathrm{m}$ - V

Kecskebéka (Rana esculenta) - h, m - V

Halak - Pisces

Ponty (Cyprinus carpio) - h

Ezüstkárász (Carassius auratus gibelio) - $\mathrm{h}$

Lapos/dévérkeszeg (Abramis ballerus/A. brama) - $\mathrm{h}$

Bodorka (Rutilus rutilus) - h

Fenćkjáró küllö (Gobio gobio) - h - V

Kinai razbóra (Pseudorasbora parva) - $\mathrm{h}$

Szélhajtó küsz (Alburnus alburnus) - $\mathrm{h}$

Réti-/vágó csík (Misgurnus fossilis/Cobitis

tania) - h - V

Naphal (Lepomis gibbosus) - h

Csuka (Esox lucius) - h

Törpeharcsa (Ictalurus nebulosus) - h

Megfigyclés módszere: $\mathrm{m}$ - terepi megfigyelés, vagy hang, cs - elevenfogó csapdázás, $\mathrm{h}$ - hullaték-, vagy köpet-analízis, a - agancs, ny - lábnyom, túrás, kaparás, $\mathrm{f}$ - fészek, $\mathrm{k}$ - kotorék

Státus: V-védett, FV - fokozottan védett 


\section{Köszönetnyilvánítás}

Köszönetünket fejezzük ki a tízlábú rákok valamint a fenékjáró küllö meghatározásáért Körmendi Sándornak, illetve Sallai Zoltánnak, továbbá egyes kétéltü fajok előfordulási adatainak átadásáért Dr. Korsós Zoltánnak. A kutatás fö támogatója a Környezetvédelmi Minisztérium (KAC asz.: 027866-01/2001), részben az OTKA (F 037557) és az MTA Bolyai Ösztöndíj Alap volt.

\section{Irodalom}

Ábrahám L., Juhász M., PINTÉr A., NagY L. 1994. Védett természeti értékek Somogyban. Múzeumi Tájékoztató, 4: 3-70.

BERINKEY L. 1966: Halak - Pisces. Akadémia Kiadó, Budapest.

Brown R., Ferguson, J., Lawrence, M., Lees, D. 1993: Federn, Spuren und Zeichen der Vögel Europas: Ein Feldführer. Aula- verlag Wiesbaden

Csorba G., Pecsenye K. 1997: Nemzeti biodiverzitás-monitorozó rendszerek X. Emlősök és a genetikai sokféleség monitorozása. Magyar Természettudományi Múzeum, Budapest.

Debrot S., Fivaz G., Mermod C., Weber J.-M. 1982: Atlas des poils des mammiferes d'Europe. Institut de Zoologic, Neuchatel.

Dely O.GY. 1983: Hüllök-Reptilia. Magyarország Állatvilága XX. kötet, Akadémiai Kiadó, Budapest.

Jedrzejewska B., Jedrzejewskı W. 1998: Predation in vertebrate communities. The Bialowicza Primeval Forest as a Case Study. Springer-Verlag, Berlin Heildelberg.

KEMENES K. I. 1993: Egy védett ragadozó, a vidra (Lutra lutra) elterjedése, táplálkozása és az ezeket befolyásoló tényezők Magyarországon. Kandidátusi értekezés.

LANSZKı J. 2002: Magyarországon élő ragadozó emlösök táplálkozás-ökológiája. Natura Somogyiensis, 4. kötet, Somogy Megyei Múzeumok Igazgatósága, Kaposvár.

KNOLLSEISEN M. 1996: Fischbestimmungsatlas, als Grundlage für nahrungsökologische Untersuchungen. Boku-Reports on Wildlife Research and Game management, Wien.

März R. 1972: Gewöll- und Rupfungskunde. Akademic Verlag, Berlin.

MóczÁR L. 1969: Állathatározó I-II. kötet. Tankönyvkiadó, Budapest.

PAUNovic M. 1990: Vodozemci iz proslosti I sadasnjosti Odredivanje skeletnih dijelova. (Kétéltủ határozó csonttani bélyegek alapján), Zagreb.

PINTÉR, K. 1989: Magyarország halai. Akadémiai Kiadó, Budapest.

Purger J.J., FENYösı L. 2001: Somogy megye madárfaunája (Aves). Natura Somogyiensis, 1: 453-479. In: Ábrahám L. (szerk.) Somogy fauna katalógusa. Somogy Megyei Múzeumok Igazgatósága, Kaposvár.

SCHMiDT E. 1967: Bagolyköpet vizsgálatok. A Magyar Madártani Intézet kiadványa, Budapest.

TeERINK B.J. 1991: Hair of West-European mammals. Cambridge University Press, Cambridge.

UjHELYı P. 1989: A magyarországi vadonélő cmlősállatok határozója. (Küllemi és csonttani bélyegek alapján) A Magyar Madártani Egyesület kiadványa, Budapest. 


\title{
Investigation on vertebrata fauna of the Látrányi Puszta Nature Conservation Area
}

\author{
JóZSEF LANSZKI AND LÓRÁNT NAGY
}

On Látrányi Puszta Nature Conservation Area (223.6 ha), situated on the south coastline of the lake Balaton, faunistic investigations of vertebrates were performed by several methods. The occurrence was investigated by direct observation in most cases; furthermore, diet analysis of carnivores and the long-eared owl, and live trapping of small mammals were performed for the investigation of the diet composition in latter case. During the survey 22 mammals (Mammalia), 56 birds (Aves), 4 reptiles (Reptilia), 5 amphibians (Amphibia) and 11 fish species (Pisces) were observed. 62 of them were protected and 2 strictly protected. The strictly protected otter (Lutra lutra) constantly occurred alongside the Tetves Stream, and the bee-eater (Merops apiaster) was a nesting species. A list of species observed, and small mammals trapped, furthermore the seasonal diet composition of the otter, the stone marten and the red fox (frequency and biomass data) were given in tables. We proposed the amplification of the east part of the protected area to the Tetves Stream, where wetland rehabilitation is needed. The amplification on the north hawthorn grass-land area is also reasoned, as this is the habitat of the spermophile (Spermophilus citellus) and numerous predatory birds. 